\title{
PENGARUH PEMANFAATAN SISTEM INFORMASI AKUNTANSI KEUANGAN DAERAH, KUALITAS SUMBER DAYA MANUSIA, DAN PENGAWASAN KEUANGAN DAERAH TERHADAP KUALITAS LAPORAN KEUANGAN PEMERINTAH ACEH
}

\author{
Nova Rosmalita ${ }^{1}$ Nadirsyah $^{* 2}$ \\ ${ }^{1,2}$ Program Studi Akuntansi Fakultas Ekonomi dan Bisnis Universitas Syiah Kuala \\ e-mail: novarosmalita25@gmail.com ${ }^{1}$,nadirsyah@unsyiah.ac.id ${ }^{2}$

\section{* Corresponding Author}

\begin{abstract}
Abstrak
The research examines the influence of the use of regional financial accounting information system, quality of human resources and regional financial supervision on the quality of the Aceh Goverment financial report. The population in this study is SKPA of Aceh Province. The sampling technique used is simple random sampling. This study uses primary data which obtained through the questionnaire results. The data were colleccted 64 questionnaires from 32 SKPA. Data analysis using multiple linear regression. The results show that together, regional financial accounting information system, quality of human resources and regional financial supervision on the quality of the Aceh Goverment financial report. Partially, each independent variable is an regional financial accounting information system, quality of human resources and regional financial supervision affects the quality of the Aceh Goverment financial report.
\end{abstract}

Keywords: Regional Financial Accounting Information system, Human Resources, Regional Financial Supervision and Quality of Financial Statements

\section{Pendahuluan}

Berdasarkan Peraturan Pemerintah Nomor 8 Tahun 2006 tentang pelaporan keuangan dan kinerja instansi pemerintah menjelaskan bahwa laporan keuangan yaitu suatu bentuk pentanggungjawan pengelolaan keuangan negara/daerah selama satu periode. Peraturan tersebut juga menjelaskan untuk menghasilkan laporan keuangan yang berkualitas atau bernilai laporan keuangan harus memenuhi beberapa kriteria yang memadai seperti dapat diandalkan, dapat dinilai atau dibandingkan, dapat dipahami dan memiliki relevansi.

Peraturan Pemerintah Nomor 71 Tahun 2010 menyebutkan bahwa laporan keuangan merupakan laporan terstruktur mengenai posisi keuangan dan transaksi-transaksi yang dilakukan oleh suatu entitas pelaporan. Laporan Keuangan Pemerintah Daerah (LKPD) terdiri atas 7 (tujuh) komponen yaitu: neraca, laporan operasional, laporan arus kas, laporan perubahan ekuitas, laporan realisasi anggaran, laporan perubahan saldo anggaran lebih dan Catatan atas Laporan Keuangan (CaLK).

Laporan Keuangan Pemerintah Daerah (LKPD) setiap tahunnya mendapat penilaian berupa opini dari Badan Pemeriksaan Keuangan (BPK). Ketika BPK mengeluarkan opini Wajar Tanpa Pengecualian (WTP) kepada LKPD, berarti dapat disimpulkan bahwa laporan keuangan suatu entitas tersebut telah disajikan dengan wajar dan memiliki kualitas. Ada empat jenis opini yang akan diberikan oleh pemeriksa yaitu opini Wajar Tanpa Pengecualian (WTP), opini Wajar dengan Pengecualian (WDP), opini Tidak Wajar (TW), dan yang terakhir pernyataan Menolak memberi opini atau Tidak Memberi Pendapat (TMP).

Menurut hasil pemeriksaan BPK (2016), berdasarkan Undang-Undang Nomor 15 Tahun 2004 tentang pemeriksaan pengelolaan dan tanggung jawab keuangan negara dan Undang-Undang Nomor 15 Tahun 2006 tentang badan pemeriksa keuangan serta Undang-Undang terkait lainnya, selanjutnya BPK telah melakukan pemeriksaan neraca Pemerintah Aceh 
per 31 Desember 2016 dan 2015. Laporan Realisasi Anggaran, Laporan Perubahan Saldo Anggaran Lebih, Laporan Operasional, Laporan Arus Kas, dan Laporan Perubahan Ekuitas, serta Catatan atas Laporan Keuangan untuk tahun yang berakhir pada tanggaltanggal tersebut. BPK telah menerbitkan laporan hasil pemeriksaan atas laporan keuangan Pemerintah Aceh tahun 2016 yang memuat opini Wajar Tanpa Pengecualian (WTP) dengan laporan nomor 13.A/LHP/XVIII.BAC/06/2017 dan laporan hasil pemeriksaan atas sistem pengendalian intern nomor 13.B/LHP/XVIII.BAC/06/2017 tanggal 9 Juni 2017. Meskipun demikian, BPK masih menemukan temuan berupa ketidakpatuhan, kecurangan dan ketidakpatutan dalam pengujian kepatuhan terhadap peraturan perundang-undangan pada Pemerintah Aceh. Namun temuan tersebut masih dalam batas wajar dan tidak material, Pokok-pokok temuan antara lain:

1) Kelebihan Pembayaran Harga Satuan Timpang dan Kekurangan Volume Pada Pekerjaan Pembangunan Gedung Kantor DPRK Masingmasing Sebesar Rp33.683.510,59 dan Rp193.575.500,00

2) Jaminan Pelaksanaan atas Pemutusan Kontrak pada Pekerjaan Pembangunan RSU Regional Langsa Belum Dicairkan Sebesar Rp263.750.000,00;

3) Pembayaran Biaya Langsung Personil Sebesar Rp129.230.416,67 dan Penentuan Pemenang Lelang atas Pekerjaan Jasa Konsultansi Pengawasan Tidak Sesuai Ketentuan;

4) Pemborosan Keuangan Daerah atas Pembayaran Premi Peserta Jaminan Kesehatan Rakyat Aceh (JKRA) Minimal Sebesar Rp63.488.418.000,00;

Berdasarkan fenomena tersebut dapat disimpulkan bahwa laporan keuangan Pemerintah Aceh belum sepenuhnya memenuhi kualitas laporan keuangan pemerintah seperti yang telah disebutkan dalam karakteristik kualitatif dalam Peraturan Pemerintah Nomor 24 Tahun 2005 Tentang Standar Akuntansi Pemerintah (SAP). Peraturan Pemerintah Nomor 24 Tahun 2005 yang menjelaskan bahwa karakteristik kualitatif yang memenuhi kualitas laporan keuangan diantaranya informasi yang termuat di dalam laporan keuangan dapat mempengaruhi keputusan pengguna dalammembantu mereka mengevaluasi peristiwa masa lalu atau masa kini dan memprediksi masa depan serta menegaskan atau mengoreksi hasil evaluasi mereka di masa lalu, bebas dari pengertian yang menyesatkan dan bebas dari kesalahan material, dapat dibandingkan dengan laporan keuangan periode sebelumnya atau laporan keuangan entitas pelaporan lain pada umumnya, dapat dipahami oleh pengguna dan dinyatakan dalam bentuk serta istilah yang disesuaikan dengan batas pemahaman pengguna.

Salah satu faktor pendukung untuk kualitas laporan keuangan adalah sistem informasi akuntansi keuangan daerah, dimana laporan keuangan dihasilkan dari suatu proses yang didasarkan pada input yang baik, proses yang baik dan output yang baik. Ketiga aspek tersebut harus terpadu dan saling berhubungan sebagai pondasi sistem pelaporan keuangan yang baik (Kurniawan \& Selamet, 2011). Diperlukan suatu sistem yang mengatur proses pengklasifikasian, pengukuran, dan pengungkapan seluruh transaksi keuangan dalam penyusunan dan pengelolaan keuangan daerah yang disebut dengan sistem akuntansi. Untuk menghasilkan informasi keuangan yang bermanfaat bagi para pemakai, maka laporan keuangan harus disusun oleh personel yang memiliki kompetensi dibidang pengelolaan keuangan daerah dan sistem akuntansi (Pujiswara et al., 2014).

Faktor pendukung lainnya untuk meningkatkan kualitas informasi laporan keuangan adalah adanya kualitas sumber daya manusia. Laporan keuangan adalah suatu produk yang dihasilkan oleh bidang atau disiplin ilmu akuntansi, oleh karena itu dibutuhkan sumber daya manusia yang berkualitas untuk menghasilkan sebuah laporan keuangan yang berkualitas. Begitu juga di entitas pemerintahan, agar laporan keuangan daerah berkualitas maka dibutuhkan sumber daya manusia yang memahami dan berkualitas dalam bidang akuntansi pemerintahan, keuangan daerah bahkan organisasional tentang pemerintahan (Tawaqal \& Suparno, 2017). Kemudian menurut Yuliani et al., (2010) untuk dapat menghasilkan laporan keuangan yang berkualitas, maka kualitas orang-orang yang melaksanakan tugas dalam menyusun laporan keuangan harus menjadi perhatian utama yaitu para pegawai yang terlibat dalam aktivitastersebut harus mengerti dan memahami bagaimana proses dan pelaksanaan akuntansi itu dijalankan dengan berpedoman pada ketentuan yang berlaku. 
Agar pengelolaan keuangan daerah menjadi baik, maka Pemerintah Aceh harus memiliki sumber daya manusia yang berkualitas. Sumber daya yang berkualitas didukung dengan latar belakang pendidikan akuntansi, sering mengikuti pendidikan dan pelatihan serta sudah mempunyai pengalaman dibidang keuangan. Hal ini diperlukan untuk menerapkan sistem akuntansi yang ada. Sumber daya manusia yang berkualitas akan mampu memahami logika akuntansi yang baik. Kegagalan sumberdaya manusia Pemerintah Daerah dalam memahami serta menerapkan logika akuntansi akan berdampak pada laporan keuangan. Laporan keuangan yang dibuat sering terdapat kekeliruan dan ketidaksesuaian laporan dengan standar yang telah diterapkan oleh pemerintah (Tawaqal \& Suparno, 2017).

Selain itu untuk menyajikan informasi keuangan yang berkualitas kepada para pengguna agar sesuai dengan rencana yang telah ditetapkan, maka diperlukan suatu upaya yang dipandang relevan yaitu pengawasan keuangan daerah (Pujiswara et al., 2014). Pengawasan keuangan daerah adalah kegiatan sistematis yang ditunjukkan untuk menjamin agar pengelolaan keuangan Pemerintah daerah berjalan sesuai dengan rencana dan ketentuan peraturan perundang-udangan yang berlaku terkait pada semua hak dan kewajiban daerah dalam kerangka penyelenggaraan pemerintahan (Subekan \& Hartoyo, 2012:38).

Pengawasan pada dasarnya diarahkan sepenuhnya untuk menghindari adanya kemungkinan penyelewengan atau penyimpangan atas tujuan yang akan dicapai. Dengan adanya pengawasan, diharapkan dapat membantu melaksanaan kebijakan yang telah ditetapkan untuk mencapai tujuan yang telah direncanakan secara efektif dan efesien. Bahkan, melalui pengawasan tercipta suatu aktivitas yang berkaitan erat dengan penentuan atau evaluasi mengenai sejauh mana pelaksanaan kerja sudah dilaksanakan, sejauh mana kebijakan pimpinan dijalankan, dan sampai sejauh mana penyimpangan yang terjadi dalam pelaksanaan kerja tersebut (Subekan \& Hartoyo, 2012:42).

Penelitian ini merujuk pada penelitian sebelumnya yang dilakuan oleh Pujiswara et al., (2014) dengan hasil pemanfaatan sistem informasi akuntansi keuangan daerah dan pengawasan keuangan daearah berpengaruh positif terhadap nilai informasi pelaporan keuangan dan akuntabilitas pemerintah daerah. Penelitian oleh Firdaus et al., (2015) dengan hasil kualitas sumber daya manusia berpengaruh terhadap kualitas laporan keuangan pemerintah daerah kota Banda Aceh.

Penelitian yang dilakukan oleh Kusuma et al., (2016) dengan hasil kualitas sumber daya manusia dan pengawasan keuangan daerah berpengaruh positif dan signifikan terhadap kualitas informasi laporan keuangan Pemerintah Daerah Jembrana. Kemudian penelitian yang dilakukan oleh Mansur et all., (2017) dengan hasil pengawasan keuangan daerah dan kualitas sumber daya manusiaberpengaruh secara simultan terhadap nilai informasi laporan keuangan Pemerintah Daerah, dan penelitian yang dilakukan oleh Tawaqal dan Suparno (2017) dengan hasil sistem informasi akuntansi dan kompetensi sumberdaya manusia berpengaruh secara simultan terhadap kualitas laporan keuangan SKPD di kota Banda Aceh.

\section{Kerangka Pemikiran dan Hipotesis}

\section{Pengaruh Pemanfaatan Sistem Informasi Akuntansi Keuangan Daerah Terhadap Kualitas Laporan Keuangan Pemerintah Aceh}

Sistem informasi akuntansi pada pemerintah daerah lebih dikenal dengan nama Sistem Informasi Keuangan Daerah (SIKD), yaitu suatu sistem yang mendokumentasikan, mengadministrasikan serta mengolah dan pengolahan keuangan daerah dan data terkait lainnya menjadi informasi yang disajikan kepada masyarakat dan sebagai bahan pengambilan keputusan dalam rangka perencanaan, pelaksanaan, dan pelaporan pertanggungjawaban pemerintah daerah. Sedangkan Informasi Keuangan Daerah adalah segala informasi yang berkaitan dengan keuangan daerah yang diperlukan dalam rangka penyelenggaraan Sistem Informasi Keuangan Daerah (Peraturan Pemerintah Republik Indonesia No 56 Tahun 2005).

Pemanfaatan sistem informasi akuntansi pemerintah dapat menghasilkan laporan keuangan yang berkualitas. Teknologi informasi dapat dimanfaatkan secara efektif jika pegawai/staf dalam lembaga-lembaga pemerintah dapat menggunakan teknologi tersebut dengan baik. Oleh karena itu adalah sangat penting bagi pegawai/staf untuk mengerti dalam menggunakan sistem tersebut (Rianisanti, 2017). 
Dalam Penelitian yang dilakukan oleh Rianisanti (2017) tentang pemanfaatan sistem informasi akuntansi keuangan daerah dan kapasitas sumber daya manusia terhadap kualitas laporan keuangan pemerintah daerah dengan sistem pengendalian intern sebagai variabel moderating pengawasan keuangan daerah, menunjukkan hasil bahwa pemanfaatan sistem informasi akuntansi keuangan daerah tidak berpengaruh terhadap kualitas laporan keuangan pemerintah daerah. Sedangkan penelitian yang dilakukan oleh Pujiswara et al., (2014) tentang Pengaruh pemanfaatan sistem informasi akuntansi keuangan daerah dan pengawasan keuangan daerah terhadap nilai informasi pelaporan keuangan dan akuntabilitas pemerintah daerah (studi pada satuan kerja perangkat daerah di Kabupaten Kungklung) menunjukkan hasil bahwa sistem informasi akuntansi keuangan daerah berpengaruh positif terhadap nilai informasi pelaporan keuangan pemerintah daerah.

\section{Pengaruh Kualitas Sumber Daya Manusia terhadap Kualitas Laporan Keuangan Pemerintah Aceh}

Menurut Salim (1996:35) kualitas sumber daya manusia merupakan nilai dari perilaku seseorang dalam mempertanggungjawabkan semua perbuatannya baik dalam kehidupan pribadi maupun kehidupan bermasyarakat dan berbangsa. Sedangkan menurut Matindas (1997:93), kualitas sumber daya manusia adalah sumber daya manusia yang bukan hanya memiliki kesanggupan untuk menyelesaikan pekerjaannya, melainkan juga untuk mengembangkan dirinya serta mendorong pengembangan diri rekanrekannya.

Penelitian mengenai kualitas sumber daya manusia terhadap kualitas laporan keuangan telah dilakukan oleh Firdaus et al., (2015) tentang pengaruh kualitas sumber daya manusia, pemanfatan teknologi informasi dan penerapan kebijakan akuntansi terhadap kualitas laporan keuangan Pemerintah Kota Banda Aceh menunjukkan hasil bahwa kualitas sumber daya manusia berpengaruh terhadap kualitas laporan keuangan. Penelitian yang dilakukan oleh Kusuma et all., (2016) tentang analisis faktor-faktor yang mempengaruhi kualitas informasi pelaporan keuangan Pemerintah Daerah Kabupaten Jembrana juga menunjukkan hasil bahwa kualitas sumber daya manusia berpengaruh positif terhadap kualitas informasi pelaporan keuangan Pemerintah Daerah Kabupaten Jembrana.

\section{Pengaruh Pengawasan Keuangan Daerah Terhadap Kualitas Laporan Keuangan Pemerintah Aceh}

Berdasarkan keputusan Presiden Nomor 74 tahun 2001 Pasal 16 tentang tata cara pengawasan penyelenggaraan pemerintah daerah, menyebutkan bahwa pengawasan pemerintah daerah adalah proses kegiatan yang ditujukan untuk menjamin agar pemerintah daerah berjalan sesuai dengan rencana dan ketentuan peraturan perundang-undangan yang berlaku. Apabila pengawasan telah dilakukan dengan baik, pengelolaan keuangan daerah akan berjalan sesuai rencana dan dapat menghasilkan kinerja keuangan yang baik yang akan terlihat pada laporan keuangan pemerintah daerah yang berkualitas.

Penelitian mengenai pengawasan keuangan daerah terhadap kualitas laporan keuangan telah dilakukan oleh Pujiswara et al., (2014) tentang pengaruh pemanfaatan sistem informasi akuntansi keuangan daerah dan pengawasan keuangan daerah terhadap nilai informasi pelaporan keuangan dan akuntabilitas pemerintah daerah (studi pada satuan kerja perangkat daerah di Kabupaten Kungklung) menunjukkan hasil bahwa pengawasan keuangan daerah berpengaruh positif terhadap nilai informasi pelaporan keuangan pemerintah daerah. Dan penelitian terdahulu yang pernah dilakukan oleh Mansur et al., (2017) analisis faktor-faktor yang mempengaruhi nilai informasi pelaporan keuangan pemerintah daerah menunjukkan hasil bahwa pengawasan keuangan daerah berpengaruh secara simultan terhadap nilai informasi pelaporan keuangan pemerintah daerah.

\section{Hipotesis}

Dalam penelitian ini dapat diambil hipotesis atau jawaban sementara penelitian, yang antara lain adalah sebagai berikut :

H1 : Terdapat pengaruh sistem informasi akuntansi keuangan daerah, kualitas sumber daya manusia, dan pengawasan keuangan daerah terhadap kualitas laporan keuangan Pemerintah Aceh 
H2 : Terdapat pengaruh sistem informasi akuntansi keuangan daerah terhadap kualitas laporan keuangan Pemerintah Aceh

H3 : Terdapat pengaruh kualitas sumber daya manusia terhadap kualitas laporan keuangan Pemerintah Aceh

H4 : Terdapat pengaruh pengawasan keuangan daerah terhadap kualitas laporan keuangan Pemerintah Aceh.

\section{Metode Penelitian}

\section{Desain Penelitian}

Tujuan studi yang dilakukan pada penelitian ini yaitu pengujian hipotesis. Pengujian hipotesis dilakukan untuk mengetahui pengaruh pemanfaatan sistem informasi akuntansi keuangan daerah, kualitas sumber daya manusia, dan pengawasan keuangan daerah sebagai variabel independen terhadap kualitas laporan keuangan Pemerintah Aceh sebagai variabel dependen. Penelitian ini merupakan studi lapangan dengan intervensi minimal, mengingat tujuan penelitian ini menguji hipotesis maka diperlukan data yang sebenarnya yaitu melalui studi lapangan pada SKPA Provinsi Aceh, unit analisi pada penelitian ini adalah individu yaitu PPK (Pejabat Penatausahaan Keuangan) dan pembantu PPK yang berkerja pada SKPA Provinsi Aceh. Waktu yang diperlukan untuk mengumpulkan data adalah cross-sectional yaitu data dikumpulkan sekaligus atau satu tahap dalam satu periode yang dilakukan dengan cara mengumpulkan kuesiner dari masing-masing staf bagian keuangan pada SKPA Provinsi Aceh.

\section{Populasi dan Sampel}

Menurut Sekaran \& Bougiie (2013:240) populasi merupakan acuan bagi peneliti untuk melakukan penelitian yang dapat berupa keselurahan kelompok, orang, kejadian, maupun minat seseorang yang ingin diinvestigasi oleh peneliti. Populasi dalam penelitian ini adalah seluruh SKPA Provinsi Aceh yang berjumlah 46 SKPA (Qanun Aceh Nomor 13 Tahun 2016). Teknik sampling yang digunakan pada penelitian ini adalah probability sampling yaitu menggunakan simple random sampling dengan cara mengadopsi rumus Slovin dalam menentukan jumlah sampel.

$$
\frac{N}{1+N \cdot e^{2}}
$$

$$
\begin{gathered}
n=\frac{46}{1+46(0,1)^{2}} \\
n=\frac{46}{1,46} \\
n=31.5068493151
\end{gathered}
$$

Berdasarkan hasil yang diperoleh, maka sampel penelitian ini sebanyak 32 SKPA, Dimana :

$$
\begin{aligned}
& \mathrm{n}=\text { ukuran sampel } \\
& \mathrm{N}=\text { ukuran populasi } \\
& e^{2}=\text { batas toleransi kesalahan (error toleransi }
\end{aligned}
$$$$
10 \%)
$$

\section{Metode Pengumpulan Data}

Teknik pengumpulan data pada penelitian ini adalah dengan menggunakan instrumen berupa kuesioner. Kuesioner diantar langsung kepada responden yakni Pejabat Penatausahaan Keuangan (PPK) dan Pembantu PPK pada Satuan Kerja Pemerintah Aceh (SKPA) Provinsi Aceh. Kuesioner masing-masing terdiri dari 1 variabel dependen dan 3 variabel independen. Pengukuran data dengan menggunakan kuesioner dapat diukur dengan menggunakan skala interval likert. Skala likert adalah skala yang digunakan dalam mengukur sikap, pendapat, dn persepsi seseorang atau sekelompok orang tentang fenomena sosial (Sugyono, 2016).

\section{Operasionalisasi Variabel Variabel Dependen}

Variabel dependen dalam penelitian ini adalah kualitas laporan keuangan Pemerintah Aceh. Kualitas laporan keuangan adalah ukuran-ukuran normatif yang perlu diwujudkan dalam informasi akuntansi sehingga dapat memenuhi tujuannya (Standar Akuntansi Pemerintahan, 2010:245). Peraturan Pemerintah Nomor 71 Tahun 2010 tentang standar akuntansi pemerintahan, menjelaskan karakteristik kualitatif laporan keuangan adalah ukuran-ukuran normatif yang perlu diwujudkan dalam informasi akuntansi sehingga dapat memenuhi tujuannya. Keempat karakteristik tersebut antara lain: (1) relevan, (2) andal, (3) dapat dibandingkan, dan (4) dapat dipahami.Variabel kualitas laporan keuangan dapat diukur dengan beberapa indikator, diantaranya adalah relevan, andal, dapat dibandingkan dan dapat dipahami. 


\section{Variabel Independen}

\section{Sistem Informasi Akuntansi Keuangan Daerah}

Menurut Silviana (2013), menyatakan bahwa sistem informasi akuntansi pada pemerintah daerah lebih dikenal dengan nama Sistem Informasi Keuangan Daerah (SIKD), yaitu suatu sistem yang mendokumentasikan, mengadministrasikan serta mengolah dan pengolahan keuangan daerah dan data terkait lainnya menjadi informasi yang disajikan kepada masyarakat dan sebagai bahan pengambilan keputusan dalam rangka perencanaan, pelaksanaan, dan pelaporan pertanggungjawaban pemerintah daerah (Peraturan Pemerintah Republik Indonesia Nomor 56 Tahun 2005). Variabel sistem informasi akuntansi keuangan daerah diukur dengan beberapa indikator, diantaranya adalah tingkat kecepatan, tingkat keamanan, tingkat pemanfaatan teknologi, tingkat efesiensi biaya, dan tingkat kualitas hasil (Modul SIA: Dunia Akntansi dan Manajemen, 2008).

\section{Kualitas Sumber Daya Manusia}

Menurut Salim (1996:35) kualitas sumber daya manusia merupakan nilai dari perilaku seseorang dalam mempertanggungjawabkan semua perbuatannya baik dalam kehidupan pribadi maupun kehidupan bermasyarakat dan berbangsa. Variabel kualitas sumber daya manusia dapat diukur dengan beberapa indikator, diantaranya adalah jumlah staf yang berkualitas, latar belakang pendidikan yang telah ditempuh, memiliki uraian peranan fungsi yang jelas, peranan dan tanggung jawab ditetapkan secara jelas dalam peraturan daerah, pelaksanaan proses akuntansi, sumber daya pendukung operasional yang cukup, dan sering mengikuti pendidikan dan pelatihan (Zuliarti, 2008).

\section{Pengawasan Keuangan Daerah}

Pengawasan keuangan daerah merupakan bagian integral dari pengolahan keuangan daerah. Berdasarkan pengertiannya, pengawasan keuangan daerah pada dasarnya mencangkup segala tindakan untuk menjamin agar pengelolaan keuangan daerah berjalan sesuai dengan rencana, ketentuan dan undangundang yang berlaku (Baswir, 1999:129). Variabel pengawasan keuangan daerah dapat diukur dengan beberapa indikator yaitu penentuan standar pengawasan, pengukuran hasil pekerjaan, perbandingan hasil dengan standar dan koreksi Penyimpangan (Terry \& Lestari W 2001:10).

\section{Hasil Dan Pembahasan Deskripsi Objek Penelitian}

Data dalam penelitiaan ini adalah data primer dengan menggunakan kuesioner sebagai sarana pengambilan datanya. Kuesioner didistribusikan ke 32 SKPA Provinsi Aceh, dimana disetiap SKPA masingmasing akan didistribusikan sebanyak 2 kuesioner yaitu kepada PPK dan pembantu PPK disetiap SKPA yang menjadi sampel penelitian. Para responden ii dipilih karea mereka merupakan pihak yang terlibat langsung dalam penyusunan laporakeuangan. Kuesioner yang didistribusikan adaah 64 kuesioner menjadi sampel penelitian. Jumlah kuesioner yang kembali adalah sebanyak 64 kuesioner atau sebesar 100\% kuesioner yang kembali.

Responden dalam penelitian ini memiliki karakteristik yang berbeda. Berdasarkan hasil penyebaran kuesioner kepada 64 responden, dapat dijelaskan bahwa adalah $56.25 \%$ adalah responden wanita sedangkan responden pria sebesar $43.75 \%$. untuk karakteristik berdasarkan usia terbanyak adalah responden yang berusia 32 orang atau sebesar 50,7\% berusia 40 tahun keatas. Untuk karakteristik berdasarkan jenjang pendidikan terbanyak adalah jenjang pendidikan strata 1 sebesar 49 orang atau $76,57 \%$. Selanjutnya untukkarakteristik berdasarkan masa kerja terbanyak adalah yang berkerja selama $>5$ tahun sebesar 67,19\%.

Penelitian yang akan dilaksanakan sebelumnya terlebih dahulu dilakukan uji kualitas data yaitu uji validitas dan uji reliabilitas, setelah itu dilakukan analisis data menggunakan uji asumsi klasik yaitu uji normalitas, uji multikolonearitas dan uji heteroskedastisitas. Kemudian, dilakukan uji hipotesis yaitu uji $f$, uji $t$, dan uji $R^{2}$ dan juga analisis regresi berganda.

Berdasarkan hasil uji kualitas data, data penelitian dikatakan valid dan reliabel sehingga dapat dilanjutkan sebagai bahan penelitian. Hasil dari data penelitian menunjukkan bahwa data penelitian normal dan bebas dari multikoloneritas maupun heteroskedastisitas. 
Hasil analisis regresi linier berganda

Coefficients $^{\mathbf{a}}$

\begin{tabular}{|c|c|c|c|c|c|}
\hline \multirow{2}{*}{ Model } & \multicolumn{2}{|c|}{ Unstandardized Coefficients } & \multirow{2}{*}{$\begin{array}{c}\text { Standardized Coefficients } \\
\text { Beta }\end{array}$} & \multirow[b]{2}{*}{$\mathbf{S t}$} & \multirow[b]{2}{*}{ Sig. } \\
\hline & $\mathbf{B}$ & Std. Error & & & \\
\hline \begin{tabular}{l|l}
1 (Constand) \\
\end{tabular} & 1.858 & 0.550 & & 3.376 & 0.001 \\
\hline SI & 0.168 & 0.079 & 0.240 & 2.135 & 0.037 \\
\hline KS & 0.225 & 0.072 & 0.353 & 3.117 & 0.003 \\
\hline PKD & 0.183 & 0.075 & 0.277 & 2.448 & 0.017 \\
\hline
\end{tabular}

a. Dependent Variable: KL

Sumber: Output SPSS (2018)

Hasil output SPSS (coefficients), dapat diperoleh persamaan regresi berganda (multiple regression) sebagai berikut:

$$
Y=1.858+0,168 X 1+0,225 X 2+0,183 X 3+e
$$

Dari persamaan regresi tersebut dapat dketahui bahwa nilai konstan sebesar 1.858. Nilai konstan ini menunjukkan bahwa apabila tidak ada variabelvariabel bebas yaitu sistem informasi akuntansi keuangan daerah, kualitas sumber daya manusia dan pengawasan keuangan daerah, maka kualitas laporan keuangan Pemerintah Aceh adalah sebesar 1.858 atau dengan kata lain, kualitas laporan keuangan Pemerintah Aceh sebesar 1.858 tanpa dipengaruhi variabel-variabel bebas.

Sedangkan koefisien regresi sistem informasi akuntansi keuangan daerah $\left(\mathrm{X}_{1}\right)$ sebesar 0,168 dan bertanda positif,artinya setiap kenaikan nilai sistem informasi akuntansi keuangan daerahsebesar 1\% maka akan meningkatkan kualitas laporan keuangan Pemerintah Aceh sebesar 16,8\% dengan asumsi variabel bebas lainnya konstan atau sama dengan nol. Koefisien regresi kualitas sumber daya manusia $\left(\mathrm{X}_{2}\right)$ sebesar 0,225 dan bertanda positif, artinya setiap kenaikan nilai kualitas sumber daya manusia sebesar 1\% maka akan meningkatkan kualitas laporan keuangan Pemerintah Aceh sebesar 22,5\% dengan asumsi variabel bebas lainnya konstan atau sama dengan nol. Koefisien regresi pengawasan keuangan daerah $\left(\mathrm{X}_{3}\right)$ sebesar 0,183 dan bertanda positif, artinya setiap kenaikan nilai pengawasan keuangan daerah sebesar $1 \%$ maka akan meningkatkan kualitas laporan keuangan Pemerintah Aceh sebesar 18,3\% dengan asumsi variabel bebas lainnya konstan atau sama dengan nol.

\section{Pengujian Hipotesis}

Pengaruh Sistem Informasi Akuntansi Keuangan Daerah, Kualitas Sumber Daya Manusia, Dan Pengawasan Keuangan Daerah Secara Simultan Terhadap Kualitas Laporan Keuangan Pemerintah Aceh

Berdasarkan hasil pengujian statistik diketahui bahwa variabel bebas yaitu sistem informasi akuntansi keuangan daerah, kualitas sumber daya manusia, dan pengawasan keuangan daerah secara simultan memengaruhi kualitas laporan keuangan Pemerintah Aceh. Hasil pengujian membuktikan dari ketiga variabel bebas tersebut seluruhnya memengaruhi kualitas laporan keuangan Pemerintah Aceh. Besarnya pengaruh variabel bebas sistem informasi akuntansi keuangan daerah, kualitas sumber daya manusia, dan pengawasan keuangan daerah terhadap kualitas laporan keuangan Pemerintah Aceh yaitu 24,6\%. Hal ini ditunjukkan oleh nilai $\mathrm{R}^{2}$ sebesar 0,246 sedangkan sisanya yaitu 0,754 atau $75,4 \%$ dijelaskan oleh variabel bebas lainnya yang tidak dimasukkan dalam penelitian ini.

Berkenaan dengan hal itu, dengan melihat adanya sistem informasi akuntansi keuangan daerah, kualitas sumber daya manusia, dan pengawasan keuangan daerah dapat memberikan gambaran bahwa ketiga variabel tersebut dapat meningkatkan kualitas laporan keuangan Pemerintah Aceh. Semakin baik sistem informasi akuntansi keuangan daerah, kualitas sumber daya manusia, dan pengawasan keuangan daerah dalam menghasilkan laporan keuangan Pemerintah Aceh, maka secara relatif akan 
meningkatkan kualitas laporan keuangan Pemerintah Aceh yang dihasilkan.

\section{Pengaruh Sistem Informasi Akuntansi Keuangan Daerah terhadap Kualitas Laporan Keuangan Pemerintah Aceh}

Berdasarkan hasil pengujian hipotesis yang dilakukan, maka dapat disimpulkan hipotesis kedua $\left(\mathrm{Ha}_{2}\right)$ diterima, yaitu secara parsial sistem informasi akuntansi keuangan daerah mempengaruhi kualitas laporan keuangan Pemerintah Aceh. Artinya, pemanfaatan sistem informasi akuntansi keuangan daerah yang digunakan sudah efektif dan efisien. Pemanfaatan sistem informasi akuntansi keuangan daerah juga membantu instansi untuk melaksanakan tugas-tugas secara mudah dan cepat. Dengan ketersediaan sistem informasi akuntansi keuangan daerah bagi instansi pemerintahan membuat biaya menjadi lebih sedikit dalam pengolahan data, dan mendukung penyajian pelaporan keuangan yang handal.

Semakin baik sistem informasi akuntansi keuangan daerah yang diterapkan oleh Pemerintah Aceh menggambarkan sistem pencatatan, pengikhtisaran, hingga pelaporan keuangan telah berjalan sesuai prosedur yang ada sehingga dapat disimpulkan bahwa sistem informasi akuntansi keuangan yang diterapkan sudah efektif, relevan, dan mengurangi kesalahan/penyimpangan serta memberikan dampak positif bagi kualitas laporan keuangan Pemerintah Aceh.

\section{Pengaruh Kualitas Sumber Daya Manusia terhadap Kualitas Laporan Keuangan Pemerintah Aceh}

Berdasarkan hasil pengujian hipotesis yang dilakukan, maka dapat disimpulkan hipotesis ketiga $\left(\mathrm{Ha}_{3}\right)$ yang telah dirumuskan sebelumnya pada penelitian ini dapat diterima, yaitu secara parsial kualitas sumber daya manusia mempengaruhi kualitas laporan keuangan Pemerintah Aceh. Hal ini menunjukkan bahwa semakin berkualitas sumber daya manusia maka kualitas laporan keuangan Pemerintah Aceh yang dihasilkan akan semakin berkualitas. Apabila kemampuan yang dimiliki oleh pegawai pengelola keuangan baik, maka output atau hasil berupa laporan keuangan akan semakin baik. Dengan adanya kualitas sumber daya manusia yang terampil dan mempunya keahlian di bidang akuntansi, memudahkan suatu instansi untuk melaksanakan fungsi dan kewenangan mencapai tujuan secara efektif dan efisien, keahlian ini dapat diperoleh dari sumber daya manusia yang berkualitas dan berkompeten guna membantu instansi di suatu pemerintahan dalam menyediakan laporan keuangan yang andal.

\section{Pengaruh Pengawasan Keuangan Daerah terhadap Kualitas Laporan Keuangan Pemerintah Aceh}

Berdasarkan hasil pengujian hipotesis yang dilakukan, maka dapat disimpulkan hipotesis keempat $\left(\mathrm{Ha}_{4}\right)$ yang telah dirumuskan sebelumnya pada penelitian ini dapat diterima, yaitu secara parsial pengawasan keuangan daerah mempengaruhi kualitas laporan keuangan Pemerintah Aceh. Hal ini menunjukkan bahwa semakin baik pengawasan keuangan daerah yang dilakukan maka kualitas laporan keuangan Pemerintah Aceh yang dihasilkan akan semakin berkualitas. Apabila pengawasan telah dilakukan dengan baik, pengelolaan keuangan daerah akan berjalan sesuai rencana dan dapat menghasilkan kinerja keuangan yang baik yang akan terlihat pada laporan keuangan pemerintah daerah yang berkualitas. Pengawasan keuangan daerah dapat membantu pemerintah dalam mengontrol kegiatan-kegiatan pada tiap-tiap instansi dalam menggunakan anggaran dan menyusun laporan keuangan. Pengawasan keuangan ini sangat penting apalagi dalam lingkup pemerintahan agar tidak terjadi hal-hal atau kecurangan-kecurangan yang dilakukan oleh oknum pemerintahan itu sendiri. Apabila fungsi dari pengawasan ini dijalankan dengan baik oleh pemerintah maka sedikit sekali terjadi kemungkinan akan adanya kecurangan serta kesalahan-kesalahan.

\section{Kesimpulan, Keterbatasan dan saran Kesimpulan}

Berdasarkan hasil pembahasan penelitian yang telah dijelaskan sebelumnya, maka dapat disimpulkan bahwa:

1) Sistem informasi akuntansi keuangan daerah berpengaruh terhadap kualitas laporan keuangan Pemerintah Aceh.

2) Kualitas sumber daya manusia berpengaruh terhadap kualitas laporan keuangan Pemerintah Aceh. 
3) Pengawasan keuangan daerah berpengaruh terhadap kualitas laporan keuangan Pemerintah Aceh.

4) Sistem informasi akuntansi keuangan daerah, kualitas sumber daya manusia, dan pengawasan keuangan daerah berpengaruh secara simultan terhadap kualitas laporan keuangan Pemerintah Aceh.

\section{Keterbatasan}

Penelitian ini memiliki keterbatasan yang dapat dipertimbangkan pada penelitian selanjutnya agar diperoleh hasil yang lebih baik lagi pada masa yang akan datang, antara lain:

1) Penelitian ini hanya meneliti pada Pemerintah Provinsi Aceh, sehingga hasil yang diperoleh tidak dapat digeneralisasikan untuk seluruh pemerintah provinsi yang ada diindonesia.

2) Aspek metodologi pada penelitian ini belum mampu menjelaskan sepenuhnya persoalan yang mungkin penting guna menggambarkan kualitas laporan keuangan Pemerintah Aceh, sehingga diperlukan pengukuran lainnya selain skala likert misalnya wawancara langsung dengan pegawai bagian keuangan.

3) Penelitian ini mengukur hanya tiga variabel terhadap kualitas laporan keuangan. Banyak variabel lain yan mungkin mempengaruhi kualitas laporan keuangan yang tidak diukur pada penelitian ini.

\section{Saran}

Berdasarkan kesimpulan dan keterbatasan penelitian di atas, maka beberapa saran yang dapat diajukan antara lain:

1. Untuk penelitian selanjutnya diharapkan dapat memperluas cakupan daerah penelitian, misalnya dengan menggenaralisasikan penelitian pada seluruh pemerintah provinsi di Indonesia sehingga menghasilkan penelitian yang lebih baik.

2. Jika memungkinkan untuk penelitian selanjutnya dapat melakukan wawancara langsung dengan pegawai bagian keuangan agar memperoleh hasil yang lebih akurat.

3. Penelitian selanjutnya disarankan untuk menambah variabel lain yang dapat mempengaruhi kualitas pelaporan keuangan seperti, pemahaman akuntansi berbasis akrual, peran internal audit, dan pemanfaatan teknologi informasi.

\section{Daftar Pustaka}

Aceh, Pemerintah. Qanun Aceh Nomor 13 Tahun 2016 (2016). Aceh.

Baswir Revrisond. (1999). Akuntansi Pemerintah Indonesia (3rd ed.). Yogyakarta: BPFE.

Firdaus, Nadirsyah, \& Heru, Fahlevi. (2015). Pengaruh Kualitas Sumber Daya Manusia, Pemanfaatan Teknologi Informasi dan Penerapan Kebijakan Akuntansi terhadap Kualitas Laporan Keuangan Pemerintah Kota Banda Aceh. Jurnal Magister Akuntansi Pascasarjana Universitas Syiah Kuala, 4(1), 45-54.

George, Terry., \& Rue Lestari W. (2001). DasarDasar Manajemen. Jakarta: Bumi Askara.

Kurniawan, \& Selamet. (2011). Penyerahan Hasil Pemeriksaan Tahun Anggaran 2010. Warta BPK.

Kusuma, Febry Perdana., Yasa, I. Nyoman Mahaendra., \& Djayastra, I. ketut. (2016). Analisis Faktor-Faktor yang Mempengaruhi Kualitas Informasi Pelaporan Keuangan Pemerintah Daerah Kabupaten Jembrana. EJurnal Ekonomi Dan Bisnis Universitas Udayana, 1(2), 4115-4150.

Mansur, Fitriani., Prasetyo, Eko., \& Maiyarni, R. (2017). Analisis Faktor-Faktor yang Mempengaruhi Nilai Informasi Pelaporan Keuangan Pemerintah Daerah. Journal of Applied Accounting and Taxation, 8(2), 143152.

Matindas, R. (1997). Kualitas Sumber Daya Manusia. Jakarta: Pustaka Utama Grafiti.

Modul SIA: Dunia Akuntansi dan Manajemen. (2008). Sofyan.blogspot.com.

Pujiswara, Ida Bagus., Herawati, Nyoman Trisna., \& Sinarwati, Ni Kadek. (2014). Pengaruh Pemanfaatan Sistem Informasi Akuntansi Keuangan Daerah dan Pengawasan Keuangan Daerah terhadap Nilai Informasi Pelaporan Keuangan dan Akuntabilitas Pemerintah Daerah (Studi Pada Satuan Kerja Perangkat Daerah di Kabupaten Klungklung). E-Journal Sl Ak Universitas Pendidikan Ganesha, 2(1).

Repubik Indonesia. Peraturan Pemerintah No. 24 
Tahun 2005 Tentang standar Akuntansi Pemerintahan (2005).

Repubik Indonesia. Undang-Undang No. 15 Tahun 2006 tentang Badan Pemeriksa Keuangan serta Undang-Undang terkait lainnya (2006).

Republik Indonesia. Keputusan Presiden No. 74 tahun 2001 Pasal 16 Tentang Tata Cara Pengawasan Penyelengaraan Pemerintah Daerah Pasal (2001).

Republik Indonesia. Peraturan Pemerintah No. 71 Tahun 2010 Tentang Standar Akuntansi Pemerintah (2010).

Republik Indonesia. Peraturan Pemerintah No. 8 Tahun 2006 Tentang Pelaporan Keuangan dan Kinerja Instansi Pemerintah (2006).

Republik Indonesia. Peraturan Pemerintah Republik Indonesia Nomor 56 tahun 2005 Tentang Tentang Sistem Informasi Keuangan Daerah (2005).

Republik Indonesia. Undang-Undang No. 15 Tahun 2004 tentang Pemeriksaan Pengelolaan dan Tanggung Jawab Keuangan Negara (2004).

Rianisanti, Dewi Meta. (2017). Pemanfaatan Sistem Informasi Akuntansi Keuangan Daerah Dan Kapasitas Sumber Daya Manusia Terhadap Kualitas Laporan Keuangan Pemerintah Derah Dengan Sistem Pengendalian Intern Sebagai Variabel Moderating (Studi Pada SKPD Kabupaten Klaten).

Salim, Emil. (1996). Aspek Sikap Mental Dalam Manajemen Sumber Daya Manusia. Jakarta: Bina Askara.

Sekaran, Uma \& Roger, Boungie. (2013). Reseacrh Methods for Business: A.Skill - Building Approach. United Kingdom: John Wiey \& Sons Ltd (sixth).

Silviana. (2013). Hubungan Penerapan Sistem Informasi Akuntansi Terhadap Kualitas Laporan Keuangan Pemerintah Daerah (Survey pada 9 Kota di Provinsi Jawa Barat). Proceeding Call For Papers Dan Seminar Nasional.

Subekan, Achmat., \& Hartoyo, Nafsi. (2012). Keuangan Daerah: Terapi Atasi Kemiskinan. Malang: DIOMA.

Sugiyono. (2006). Metode Penelitian Kuantitatif, Kualitatif, dan R\&D. Bandung: ALFABETA.

Tawaqal, Irza., \& Suparno. (2017). Pengaruh Penerapan Sistem Informasi Akuntansi, Sistem
Pengendalian Internal, dan Kompetensi Sumber Daya Manusian terhadap Kualitas Laporan Keuangan Satuan Serja Perangkat Daerah Di Pemerintah Kota Banda Aceh. Jurnal Ilmiah Mahasiswa Ekonomi Akuntansi (JIMEKA), 2(4), 125-135.

Yuliani, Safrida, Nadirsyah, \& Usman Bakar. (2010). Pengaruh Pemahaman Akuntansi, Pemanfaatan Sistem Informasi Akuntansi Keuangan Daerah dan Peran Internal Audit terhadap Kualitas Laporan Keuanga Pemerintah Daerah. Jurnal Telaah \& Riset Akuntansi, 3: 206-220.

Zuliarti. (2008). Pengaruh Kapasitas Sumber Daya manusia, Pemanfaatan Teknologi Informasi, dan Pengendalian Intern Akuntansi Terhadap Nilai Informasi Pelaporan Keuangan Pemerintah. Studi Pada Pemerintah Kabupaten Kudus. Muria Kudus. 